JEL Classification: J22, J31, I38

Keywords: labor supply, welfare trap, net replacement rate

\title{
An Empirical Analysis of Welfare Dependence in the Czech Republic*
}

\author{
Martin GUZI-Masaryk University, Brno, Czech Republic, and CELSI (Central European Labor \\ Studies Institute), Bratislava, Slovakia (Martin.Guzi@econ.muni.cz)
}

\section{Abstract}

The scope of this paper is to empirically test whether the potential disincentive effects of the Czech social security system affected the labor flows from unemployment to employment over the period 1995-2005. Combining individual data from the Czech Labor Force Survey and the Czech Household Income Survey, the analysis exploits the difference between the available social benefits and the net household income when a person is employed. Estimates imply that individuals who receive relatively higher social benefits are also more likely to remain unemployed and it is shown that the groups most affected are those with low education and long spells of unemployment. The paper confirms that the level and persistence of unemployment in the Czech Republic after 2000 can be partly attributed to the nationwide level of social support that constitutes a welfare trap for some individuals.

\section{Introduction}

The combination of tax and social security systems affects labor market dynamics. The scope of this paper is to explore whether the potential disincentive effects created by the Czech tax and social security systems reduced the labor flows from unemployment to employment over the period 1995-2005. The employment and social policies are subject to incentive compatibility constraints given that they have to make work pay. The interaction of tax and social security systems defines the disposable income of individuals and, therefore, influences the decision of the unemployed to accept a job.

In the late 1990s, the amount of social benefits paid to the unemployed was relatively generous; indeed, the Czech social welfare system was ranked the second most generous in the OECD in 1996 (OECD, 1998). ${ }^{1}$ Moreover, the incremental benefit provided to families with children was proportionally larger in the Czech Republic than in any other OECD country (OECD, 1998). OECD studies pointed out that the combination of benefit withdrawal and the tax system in the Czech Republic could lead to a distorted labor supply (OECD, 1998; OECD, 2004). In 1998, OECD representatives issued the recommendation for the Czech Republic to "re-examine the basis upon which benefits in the social assistance and state social support system are determined. To preserve work incentives, additional benefits awarded to larger families need to be reduced in line with international practice". ${ }^{2}$ At the same time,

\footnotetext{
* This work was supported by the project "Employment of the Best Young Scientists for International Cooperation Empowerment" (CZ.1.07/2.3.00/30.0037) co-financed from the European Social Fund and the state budget of the Czech Republic. I would like to thank Daniel Munich, Kamil Galuscak, Jozef Zubicky, Ondrej Schneider, Ricarda Schmidl, Jan Kmenta, Randall Filer, Mikolaj Herbst, Michael Moritz and two anonymous referees for their valuable comments. All errors remaining in this text are the responsibility of the author.

${ }^{1}$ The benefit generosity is compared relative to the average economy wage rather than in absolute terms

${ }^{2}$ OECD (1998), p. 87
} 
the economic transformation in the late 1990s prompted a steep increase in the unemployment rate. The unemployment rate doubled following the recession in 1997, while the long-term unemployment rate more than tripled between 1996 and 2000 (see Figure 1 in Appendix 1). After 2000, the unemployment rate remained high even though the economy was growing (see Jurajda and Munich (2003) for discussion).

The tax and social security systems in the Czech Republic were assessed by several studies as generating a welfare trap for a wide range of households (e.g. Jahoda, 2004; Schneider, 2004; Jurajda and Zubricky, 2005; Flek and Vecernik (2005); Galuscak and Pavel, 2007). Results from studies suggest that high net replacement rates are likely to attenuate work incentives for individuals with children, as well as those who have lower chances of getting a better-paid job. For these individuals, the potential income from employment may not be significantly higher relative to the available income from social benefits. Galuscak and Pavel (2007) estimate that around onethird of all employed individuals in the Czech Republic in 2006 had low incentives to avoid short spells of unemployment given that it did not significantly reduce their earnings. These findings are typically based on the theoretical considerations for selected types of households, with the potential income of the unemployed usually approximated with the income of the average production worker in the economy and compared to the amount of available benefits.

Several studies (e.g. Sorm and Terrell, 2000; Lauerova and Terrell, 2005) have examined the behavior of the unemployed in the Czech labor market directly using microdata but have not considered the role of social benefits. One exception is the study of Commander and Heitmueller (2007), who use microdata and empirically test the impact of social benefits on the labor supply behavior of the unemployed in the Czech Republic, Hungary and Poland. However, the measure of the generosity of social benefits is simplistic in their analysis, with the authors assuming the average level of benefits relative to the national average wage for several household types. The high approximation of social benefits at the household level reflects the main drawback of the paper and, consequently, the authors find only weak evidence for the role of social benefits in the Czech labor market.

This paper explores the idea from Commander and Heitmueller (2007) but significantly improves the computations of household income under working and non-working alternatives. Given that the Czech Labor Force Survey does not include any income information, the Czech Household Income Survey is used to estimate potential income in the local labor market for the unemployed. This information allows us to calculate the net replacement rate (NRR) based on the parameters of the taxation system and rules for means-tested social benefits at the household level. The analysis subsequently proceeds to examine the link between the generosity of social benefits and individual labor supply behavior. The purpose of the paper is to test the hypothesis that high social benefits constitute a welfare trap for the unemployed and to identify the existence of a welfare trap among different groups.

The focus of the analysis is on the period 1995-2005, during which the long-term unemployment rose from $2 \%$ to $6 \%$. We explore the extent to which the development of unemployment can be attributed to the state social support scheme. Based on the findings from recent studies which evaluate changes in the tax and social security systems introduced in 2007 and 2008, we conclude that the main findings from the analysis are valid and that the welfare trap is still present in the Czech social system. 
The remainder of the paper is organized as follows: the next section discusses the empirical findings of labor market policies on individual labor supply behavior. Section 3 describes the Czech social security system. Section 4 proposes a simple job-search model to derive the behavior of the unemployed with available social benefits. Section 5 provides a description of the data set used and presents summary statistics. The calculation of NRR for each household is described in Section 6, while Section 7 presents the findings and Section 8 concludes the paper.

\section{Literature Review}

Both active and passive labor market policies were introduced in the transition economies during the 1990s to relieve tensions in the labor market and provide income support for jobless workers. Government interventions through an active labor market policy (ALMP) provide training and guidance to the unemployed. Indeed, it is documented that the increased expenditure on ALMP has a positive impact on employment prospects in EU-15 countries, and it has also been shown that youth measures and public employment services reflect the most efficient allocation of ALMP resources (European Commission, 2004). The level of expenditure on ALMP is substantially lower in the countries of Central and Eastern Europe (CEE), and thus it is not surprising that unemployment development does not seem to be affected by ALMP in these countries (Lehmann and Muravyev, 2009). The weak efficiency of ALMP programs in the Czech Republic was previously confirmed in Munich, Svejnar and Terrell (1999). Flek and Vecernik (2005) mention that expenditure on ALMP appeared to be insufficient to reverse the rising unemployment rate in the Czech Republic in the late 1990s.

Passive labor market policies ensure that individuals can subsist during periods of unemployment with more resources allocated to these programs. ${ }^{3}$ On the one hand, the availability of income support for the unemployed renders joblessness less painful, thus allowing for a longer job search that leads to a better job match in the labor market. Wulfgramm and Fervers (2013) find that workers in European countries with more generous income support for the unemployed achieve higher employment stability upon re-employment. The authors suggest that this outcome is possibly driven by the intensity of ALMP programs via skill level increases and information deficit reductions.

On the other hand, generous social benefits can negatively affect the jobsearch intensity of unemployed workers and, conditional on the wage offered, higher benefits reduce the economic incentives to accept a job offer. The literature provides many examples showing that most of the unemployed want to work and the evidence of negative aspects of welfare participation on transition to work is documented. In Germany, Schneider and Uhlendorff (2006) confirm that transitions to employment during 1992-2000 were more likely to be observed for unemployed individuals with a higher potential wage relative to the level of social benefits. Portugal and Addison (2008) identify disincentive effects of unemployment benefits on the exit rate from unemployment using Portuguese employment surveys between 1992 and 1997. Petrongolo (2009) evaluates the UK reform in 1996 that introduced tighter search requirements for social benefit claimants. She concludes that the reform was success-

\footnotetext{
${ }^{3}$ The Ministry of Labor and Social Affairs reports that the share of ALMP in GDP was $0.07 \%$ during the period 1995-2000. The average spending on passive programs amounted to $0.23 \%$ of GDP.
} 
ful in moving unemployed individuals into the labor market through raising the costs of remaining on social benefits. Van Ours and Vodopivec (2006) find that the rate of finding jobs among the unemployed in Slovenia largely increased after 1998, when the benefit entitlement period was substantially shortened. The exit rate remained unchanged for the unemployed whose entitlement period did not change; therefore, the authors interpret the effect as causal. Boeri (2000) finds a positive relationship between the level of social benefits and the (self-reported) reservation wages of individuals in the transition countries with generous social benefits increasing the opportunity costs of employment and leading to high reservation wages. Boeri explains that the distribution of reservation wages does not increase uniformly but rather rises predominantly at its lower end. Consequently, high social benefits increase the chances of low-productive workers remaining out of employment.

Both the tax and social security systems contain measures targeted at poorer households and families with children. Prusa (2001) discusses the redistribution and tax policies in the Czech Republic prior to 2000 and Jahoda (2004) in 2003. Both studies conclude that there is little interaction between these two systems with the welfare trap likely to arise for low-income individuals who transition from unemployment to employment. Schneider (2004) shows that the tax and social security systems in the Czech Republic heavily redistribute income towards low-income groups. Working with aggregate figures from 2001, Schneider finds that taxes rise and social benefits are withdrawn when household income moves up from the bottom decile, creating strong disincentives for labor market participation. Similarly higher benefits targeted to families with children may lock individuals in unemployment due to the welfare trap. Jurajda and Munich (2003) use the 2001 Czech Labor Force Survey to show that the propensity for long-term unemployment increases largely in families with more than three children. Jurajda and Zubricky (2005) discuss the parameters of the tax and social security systems, showing that the level of social benefits for individuals from low income and large families remains relatively high in the case of long-term unemployment. Therefore, the guaranteed household income from social benefits suggests very little motivation for individuals to exit unemployment.

Several studies have empirically examined the behavior of the unemployed in the Czech labor market using microdata. Ham, Svejnar and Terrell (1998) use data on unemployed men from 1991-1993 to show that higher unemployment benefits and a longer entitlement period lead to longer unemployment duration. However, the authors argue that the estimated elasticities are moderate and comparable to estimates obtained from Western Europe. The important finding demonstrated by the authors is that in the early 1990s the Czech labor market absorbed the low-skilled unemployed at a rate similar to the rate at which it absorbed the skilled unemployed. The study by Sorm and Terrell (2000) analyzes worker mobility across different labor market states during 1994-1998. It considered individual characteristics as determinants of labor mobility and concluded that labor market flows during the studied period were efficient with a low incidence and short duration of unemployment. Lauerova and Terrell (2005) explore the female-male differences in labor market flows over the period 1993-1996, finding that women have significantly lower probabilities of exiting unemployment than men. Such chances are particularly low for married women. Commander and Heitmueller (2007) study flows in the labor market with respect to the role of social benefits during 1993-2003, finding weak evidence that individual decisions to transition 
from unemployment to employment relate to the amount of social benefits. However, this result can be partly attributed to the fact that the authors use a simple approximation of benefit generosity at the household level.

The findings from the literature evaluating the dynamics in the Czech labor market are very inconclusive. The findings based on income simulation for selected households suggest that the combination of the tax and social security systems in the Czech Republic creates a welfare trap, i.e. social benefits are accepted as an alternative to low and insecure earnings. Empirical studies find that the less educated tend to have a higher incidence and longer duration of unemployment, though the association between social benefits and high unemployment was not directly confirmed. This paper fills the gap and demonstrates the existence of a welfare trap, finding a negative influence of the high NRR on the probability of transitioning from unemployment to employment.

\section{The Czech Social Security System}

The Czech government implemented extensive reforms to its tax and social security systems in the early 1990s. The social security system described in this paper was introduced in 1995 and had only undergone minor changes until 2005 . $^{4}$ Workers who become unemployed are eligible to receive unemployment benefits for a period of six months with the amount calculated from their previous net income. The unemployed who are jobless for more than six months are entitled to social benefits of unlimited duration. Social benefits are not taxable and are subject to means testing. In practice, they are paid to keep household income above the minimum subsistence level (MSL), which is defined by the Ministry of Labor and Social Affairs and represents the minimum amount of money that a household of a given composition would require for its subsistence. The MSL scheme defines a personal benefit for individuals by age and a household supplement to cover necessary household expenses. The generosity of the social system is illustrated in Table 1, which shows MSL benefits expressed in percentages relative to the net income of an average production worker. The MSL for a given household is defined as the sum of personal benefits of all family members and the household supplement. Table 2 in Appendix 1 demonstrates the MSL computed for several typical households. It is observed that the MSL was initially set at relatively high levels before falling over time. Galuscak and Pavel (2007) calculate that while the average wage in the Czech economy between 1996 and 2006 increased by 106\%, the amount of social benefits rose by $66 \%$ for single individuals, $57 \%$ for a couple without children, and $51 \%$ for a couple with two children. The authors explain that this decreasing trend in benefit generosity mainly occurred due to relatively high (wage) inflation and a lack of indexation of social benefits. However, social benefits remained relatively high for some groups throughout this period. It should be noted that it is standard to express social benefits relative to the national average wage despite the income of the majority of workers being lower. Therefore, the presented values are taken as a lower boundary to illustrate the generosity of social benefits.

Previous studies emphasized that higher social benefits targeting families with children may constitute a potential welfare trap. As an example, Table 2 illustrates

\footnotetext{
${ }^{4}$ For a detailed description of the Czech tax and benefit systems, see Galuscak and Pavel (2007). An update to the tax-benefit policy is published annually at http://www.oecd.org/social/benefits-and-wages.htm.
} 
that the guaranteed income from social support for a couple (if both spouses are unemployed) with two children in 2000 was at $102 \%$ of the national net monthly wage of an average production worker. The amount of benefits at that level may constitute sufficient income for a family residing in a depressed region, while rendering an employment alternative as a less attractive option. However, benefit dependency among the long-term unemployed can lead to mental, social and material deprivation as documented by Mares and Sirovatka (2005) in the Czech Republic.

\section{Theoretical Framework}

A simple job-search model represents a useful framework to illustrate the likely impact of social benefits and job-search intensity on the transition from unemployment to employment. This model is familiar within the existing literature on jobsearch theory formalized by Mortensen (1986). In the model, individuals can be either employed or unemployed and maximize the lifetime utility in continuous time. Unemployed individuals receive benefits $b$ and invest search time (or intensity) $s=[0,1]$ to find a job. Search effort cost $c(s)$ generates job offers at rate $\lambda(s)$ from a known wage distribution $F(w)$. The standard assumption follows that search costs are convex in effort while returns are concave, thus

$$
c^{\prime}(s)>0, c^{\prime \prime}(s)>0, \lambda^{\prime}(s)>0, \lambda^{\prime \prime}(s)<0
$$

Employed individuals are paid a wage $w$ and face an exogenous risk of job loss $\delta$. An individual who has a job does not search for another one. The unemployed choose an optimal level of job-search effort $s$ and determine the optimal reservation wage $w_{R}$. The flow value of unemployment and employment can be written as follows, respectively:

$$
r U=\max _{s, w_{R}}\left\{b-c(s)+\lambda(s) \int_{w_{R}}[W(w)-U] d F(w)\right\}
$$

and

$$
r W(w)=w+\delta[U-W(w)]
$$

where $r$ represents the intertemporal discount rate. In theory, the reservation wage is defined at the level that makes a jobseeker indifferent between accepting a job and remaining unemployed. From $r W\left(w_{R}\right)=r U$ it follows that the flow value of unemployment is equal to the reservation wage $r U=w_{R}$, which is derived from (1) as a function of the parameters of the model:

$$
w_{R}=r U=\max _{s}\left\{b-c(s)+\frac{\lambda(s)}{r+\delta} \int_{w_{R}}[1-F(w)] d w\right\}
$$

The optimal reservation wage is an implicit function of benefits and search intensity. The optimal search effort $s^{*}$ is set at the level that maximizes the intertemporal utility of a jobseeker. The first order condition for the choice of search intensity is obtained by differentiating formula (2):

$$
c^{\prime}\left(s^{*}\right)=\frac{\lambda^{\prime}\left(s^{*}\right)}{r+\delta} \int_{w_{R}}[1-F(w)] d w
$$


Equations (2) and (3) form a system that implicitly determines the reservation wage and search effort. From equation (2), it follows that a higher $b$ increases the reservation wage while rendering unemployment more attractive relative to employment. Formally:

$$
\frac{d w_{R}}{d b}=1-\frac{\lambda(s)}{r+\delta}\left[1-F\left(w_{R}\right)\right] \frac{d w_{R}}{d b}=\frac{r+\delta}{r+\delta+\lambda(s)\left[1-F\left(w_{R}\right)\right]}>0
$$

The dependence of the reservation wage on search effort is ambiguous in sign given that differentiation leads to:

$$
\frac{d w_{R}}{d s}=\frac{r+\delta}{r+\delta+\lambda(s)\left[1-F\left(w_{R}\right)\right]}\left\{\frac{\lambda^{\prime}(s)}{r+\delta} \int_{w_{R}}[1-F(w)] d w-c^{\prime}(s)\right\}
$$

A search effort below the optimal level implies a positive effect, while a search effort above the optimal search level implies a negative effect on utility. In the basic model, a rise in benefit increases the reservation wage, but it is assumed that search effort is not conditional on a benefit that is unsatisfactory. The next step is to define the search effort as an implicit function of benefit. Differentiating equation (3) with respect to $b$ implies:

$$
c^{\prime \prime}\left(s^{*}\right) \frac{d s^{*}}{d b}-\frac{\lambda^{\prime \prime}\left(s^{*}\right)}{r+\delta} \int_{w_{R}}[1-F(w)] d w \frac{d s^{*}}{d b}+\frac{\lambda^{\prime}\left(s^{*}\right)}{r+\delta}\left[1-F\left(w_{R}\right)\right] \frac{d w}{d b}=0
$$

With the help of (4), the result is:

$$
\frac{d s^{*}}{d b}=\frac{\lambda^{\prime}\left(s^{*}\right)\left[1-F\left(w_{R}\right)\right]}{r+\delta+\lambda\left(s^{*}\right)\left[1-F\left(w_{R}\right)\right]}\left[\frac{\lambda^{\prime \prime}\left(s^{*}\right)}{r+\delta} \int_{w_{R}}[1-F(w)] d w-c^{\prime \prime}\left(s^{*}\right)\right]^{-1}<0
$$

An unemployed person finds a job at rate $\lambda\left(s^{*}\right)\left[1-F\left(w_{R}\right)\right]$; therefore, higher benefits effectively decrease the job finding rate via both a decrease in jobsearch effort and an increase in the reservation wage. This result implies that higher benefits increase the duration of unemployment.

\section{Data}

\subsection{Data and Sample Selection}

The empirical analysis relies on the quarterly Labor Force Survey (LFS) data from 1995 to $2005 .{ }^{5}$ It is a rotating sample, and each quarter $20 \%$ of individuals in the sample are replaced. The survey design allows the tracking of individuals over two consecutive periods (quarters) in order to identify the change of individual labor market status in the second period. The LFS follows the ILO definition of unemployment, i.e. an unemployed person has no employment, actively searches for a job, and is able to accept a job offer. In the Czech Republic, registration with the labor

\footnotetext{
${ }^{5}$ Labor Force Survey data for the Czech Republic have been collected quarterly since 1993 by the Czech Statistical Office (CSU). Sample sizes cover more than 250,000 individuals per year. The number of respondents is proportional to the size of the district. Households are chosen randomly and all members of households are surveyed.
} 
office is necessary in order to collect social benefits, though labor offices have limited tools to screen the willingness of the unemployed to work (Galuscak and Munich, 2007). The aim of the paper is to demonstrate the existence of a welfare trap and therefore the analysis concentrates on the group of unemployed eligible to receive social benefits of unlimited duration. The final sample includes individuals who are jobless for longer than six months; therefore, they can collect social benefits and their household income never falls below the MSL (see Section 3). The final sample includes the unemployed who are the heads of households or spouses. Other persons living in the household, such as the parents of spouses or other relatives, do not enter the analysis (around 2\% of the sample). Due to different retirement schemes, the sample is limited to working-age individuals in the range of $18-54$ years. $^{6}$ Individuals who report full health disability are dropped from the sample. The LFS contains information about personal characteristics such as age, gender, the highest level of educational attainment, unemployment duration and the type of activity performed prior to unemployment. Family composition and information about the age and number of children in the household are used to determine the MSL. Unfortunately, the LFS contains no income information, which is therefore obtained from the Czech Household Income Survey collected by the Czech Statistical Office in $2002 .^{7}$

\subsection{Summary Statistics}

The final sample includes 28,338 unemployed individuals, of whom around two-thirds comprise women. Table 3 in Appendix 1 presents the descriptive statistics of the variables used in the analysis, reported separately for men and women. On average, the transition from unemployment to employment is observed for $9 \%$ of individuals and does not differ between genders. The individuals who transition from unemployment to inactivity are treated as unemployed and their inclusion does not have an effect on the final results (around $2.6 \%$ of flows from unemployment). In terms of educational attainment, women are more educated relative to men in the sample. Overall, the majority of unemployed (77\%) attained lower secondary or primary education. Men in the sample are slightly older than women, while the share of married women is higher than the share of married men. In terms of activity performed prior to unemployment, a quarter of unemployed women worked in the household or provided childcare. By contrast, most unemployed men were employed prior to becoming unemployed, and about 12\% engaged in other activities (such as military service or education). Longer detachment from the labor market can nega-

\footnotetext{
${ }^{6}$ In 1995 , the statutory retirement age was 60 for men and 57 for women with no children, 56 for women who raised one child, 55 for women who raised two children and 54 for women with three or more children.

${ }^{7}$ The Czech Household Income Surveys were collected in 1996 and 2002. The later survey is chosen while Filer, Jurajda and Planovsky (1999) show that the Czech wage structure stabilized in the late 1990s. The standard Heckman (1979) model is applied to estimate the wage equation on the sample of workers taking into account the selection to employment. Income is estimated for the sample of individuals 18-54 years old who are full-time employees, excluding the self-employed, students and persons working less than 30 hours per week. Family characteristics such as the presence of children, other household income and the presence of employed persons other than the spouse are used to estimate participation in the labor market. A potential full-time gross monthly wage is estimated for every individual in the LFS sample and the estimation is performed separately by gender. The estimated wages for years other than 2002 are subsequently adjusted for regional wage growth (see Appendix 2 for details).
} 
tively affect future prospects in the labor market. Interestingly, the share of unemployed by duration is almost identical by gender. Since 2002, the Czech LFS has included information on job-search channels used by the unemployed to seek work in the last period. ${ }^{8}$ Job-search intensity is constructed as the number of search channels used. On average, unemployed individuals report using three channels to seek employment, with higher search intensity likely to accelerate the transition to employment. Given that the gender differences in personal characteristics and incentives to exit unemployment are expected to lead to different results, an analysis is also performed separately by gender.

\subsection{Regional Patterns}

One of the key sources of variation for the analysis lies in the spatial heterogeneity in the economic conditions and in the nationally determined policy because differences in employment opportunities between districts are not reflected in the social security system, i.e. the MSL is based solely on household composition. However, wages are set in the local labor market, and thus the actual generosity of social benefits varies geographically. Taking information from statistical yearbooks of the Czech Statistical Office, Table 4 in Appendix 1 documents the wage differentials and the widening unemployment rate between districts over time. In every year, 77 districts are divided into quintiles by the level of the average wage in the district relative to the national wage and by the district unemployment rate. Average values for districts in the first and fifth quintiles are reported. In particular, the districts in the first wage quintile record between $79 \%$ and $86 \%$ of the national gross wage, while districts in the fifth wage quintile record between $102 \%$ and $107 \%$ of the national gross wage. The variation in the unemployment rate between districts is even more pronounced, increasing from $6 \%$ to $15 \%$ in districts in the fifth quintile, while remaining below 5\% in districts in the first quintile over the period 1995-2005. These findings imply that territorial differences in earnings opportunities determine the relative generosity of social benefits and therefore the working prospects of the unemployed. In this paper, regional variation in earnings opportunities is accounted for in the NRR calculations. The district unemployment rate is included in the main analysis to control for labor demand in the labor market (the same result is obtained if the vacancy-unemployment ratio is used rather than the unemployment rate). ${ }^{9}$

\section{Household Welfare Participation}

\subsection{Income Estimation}

Household net income is obtained under two alternatives in order to test the impact of welfare participation on an individual's labor supply decision. First, the individual potential gross income under the working alternative is obtained from

\footnotetext{
${ }^{8}$ The following seven search channels are considered: looking for a job through a public employment office, through a private employment agency, through friends or relatives, contacting employers directly, inserting or answering advertisements in newspapers or journals, studying advertisements in newspapers and journals, or by other means.

${ }^{9}$ The district unemployment rate is a sufficient control for demand-side effects if labor demand elasticities remain unchanged over time. Babecky, Galuscak and Lizal (2011) show that firm-level labor demand elasticities remained broadly constant in the Czech Republic from 1993 to 2009.
} 
the complementary data set for every person and their spouse in the sample (see Appendix 2 for details). Subsequently, household net income is computed based on the parameters of the tax and social security systems and accounts for family composition. Calculations account for personal income tax, with social security contributions and rules for means-tested social benefits applied. ${ }^{10}$ In contrast to previous studies, the estimation of household income is significantly improved in this paper. Commander and Heitmueller (2007) assume NRR computed for ten household types relative to the national average wage, while Galuscak and Pavel (2007) undertake the estimation assuming that the potential entry wage for the unemployed equals $50 \%$ or $67 \%$ of the national average wage.

Second, personal income under the non-working alternative is approximated by the MSL of the household, under the assumption that the household collects the available social benefits. Mares (2001) roughly estimates non-take-up rates in the Czech Republic to vary between $10 \%$ and $30 \%$ depending on the type of social benefit, which is rather satisfactory. If an unemployed person lives with a working spouse, the household income is equal to the sum of the net income of the working spouse and means-tested social benefits.

\subsection{Net Replacement Rates}

Having household income under both working and non-working alternatives enables us to calculate the NRR for every individual, which is expressed as the ratio of net household income when a person is unemployed to the net household income under the alternative situation when the individual is employed. NRR represents a useful measure to assess the link between generous social benefits and unemployment persistence (e.g. Commander and Heitmueller, 2007; Jurajda and Zubricky, 2005). The ratio takes values from 0 to 1 , with a higher NRR increasing the reservation wage of the unemployed, thereby reducing incentives to enter employment. For example, an NRR close to 1 means there are no monetary incentives to look for a job given that the household receives the same level of income regardless of employment status. However, if accounting for other costs associated with the job search and the costs of participation in the labor market (i.e. transportation costs), even an NRR lower than 1 provides little incentive to search for a job. Table 5 details the average NRR computed for the total LFS sample as well as separately for men, women and groups of different characteristics. The decreasing trend of the NRR reflects the declining generosity of the social security system. Rates are significantly higher for women relative to men, which is attributed to their lower earning opportunities in the labor market. The lowest rates are recorded for men and highly educated individuals who have better prospects in the labor market in terms of high potential earnings. Conversely, the highest rates are observed for individuals with children and those who are low-educated. A clear pattern emerges indicating that the NRR increases with the length of unemployment, which points to the selection of unskilled individuals for long-term unemployment. The share of individuals with an NRR

\footnotetext{
${ }^{10}$ I thank Stepan Jurajda and Jozef Zubricky who collected the parameters of tax and social benefit systems in the Czech Republic for the period 1995-2005. I adapted their calculations of net income and social benefits from excel tables to STATA (do-files are available upon request).
} 
above 0.8 is calculated at the bottom of Table 5. The pattern shows that the incidence of high social benefits is prevalent among the unemployed with children, the loweducated, and the long-term unemployed. Therefore, the existence of a welfare trap is likely to be present among these groups.

\section{Results}

In this section, we test for the effect of the NRR on the transition probabilities of the unemployed to employment, controlling for individual socio-demographic characteristics, local labor market attributes, and regional and time-fixed effects.

\subsection{Estimation Strategy}

The model is estimated as the reduced form equation defined as the probability of transition from unemployment to employment. The indicator function $E$ is defined. The individual makes the decision to remain unemployed $\left(E_{i}=0\right)$ rather than enter employment for which they are qualified $\left(E_{i}=1\right)$ because earnings or other working conditions are less attractive than the option of not working. In the estimation, constraints on the demand side are approximated by local labor market characteristics (i.e. the district unemployment rate and regional fixed effects). The key variable in the model is the incentive to enter employment in the presence of social benefits. The probability of transitioning from unemployment to employment is expressed as:

$$
P\left(E_{i}=1 \mid X_{i}\right)=\Phi\left(\alpha N R R_{i}+X_{i} \beta\right)
$$

where NRR is the ratio of household income under the non-working and working alternatives, $X_{i}$ includes individual characteristics, $\Phi($.$) is the logistic cumulative$ distribution function, and equation (5) is estimated by the standard Logit model. The estimated coefficient on NRR tests for the existence of the welfare trap. In order to explore the hypothesis, the sensitivity of the estimated parameter is explored among different groups of unemployed but also to the inclusion of job-search intensity.

\subsection{The Effect of Social Benefits on the Transition from Unemployment to Employment}

Equation (5) is estimated for different groups with the results reported in Table 6. Column 1 shows the baseline model estimates from the total sample. The coefficient on NRR is significant and negative, in line with the hypothesis, which means that individuals who receive relatively higher social benefits are also more likely to remain unemployed. Estimates imply that, ceteris paribus, if the NRR were to decrease from a value of 0.8 to 0.68 (a decrease of one standard deviation to the mean value), there would subsequently be an associated change in the transition probability from $8.7 \%$ to $9.2 \%$. The existence of the welfare trap and its prevalence among different groups is discussed further below. The estimated effects of demographic characteristics on transition probabilities are consistent with the previous literature. Estimates imply that married persons are more likely to leave unemployment for a job, as empirically confirmed by Sorm and Terrell (2000). Unemployed 
persons who live with an employed spouse exhibit a higher propensity to enter employment. Coefficients on a female dummy in Table 6 are negative, thus suggesting that women are disadvantaged in the transition to employment with at least two reasons discussed within the existing literature. Women are placed in a disadvantaged position first by having responsibility for childcare (Bicakova, 2010) and second by lower earnings opportunities in the labor market (Jurajda, 2003). The presence of young children in the family implies a negative impact although variables are not significant at the conventional levels. ${ }^{11}$ In general, people with less education have a lower propensity to enter employment relative to those with more education. Furthermore, workers who were not employed prior to unemployment display a lower ability to exit unemployment. This predominantly concerns women who worked in the household or provided childcare. A longer duration of unemployment has a rather strong negative effect on the outflow from unemployment. All individuals in the sample have been unemployed for at least six months. Estimates imply that the chances of exiting unemployment decrease by around three percentage points for those unemployed for longer than 12 months and by 7 percentage points if the period of unemployment lasts for more than two years. Individuals with partial health disability have a lower propensity to leave unemployment for a job by 3 percentage points. A higher unemployment rate in the local labor market indicates fewer employment opportunities and consequently lower chances of finding a job. Estimates from the baseline model in Column 1 imply that, ceteris paribus, an increase of one standard deviation in the unemployment rate is associated with a decline of 0.25 percentage point in the propensity to leave unemployment for employment.

Finally to confirm that results are not driven by the number of children, the equation is estimated including the interactions of the NRR with the number of children in the household. ${ }^{12}$ The estimates confirm the robustness of the benchmark regression, while the effect of the NRR is negative and significant (the size of the coefficient is larger in magnitude -4.2 and significant at the $5 \%$ level) and the interaction terms are not significant.

\subsection{Which Groups Are Affected?}

The transition from unemployment to employment varies with economic incentives. Previous studies indicate that motivation may be particularly low for those unemployed with children as well as for individuals who have lower chances of getting a better-paid job. To test this hypothesis, equation (5) is estimated separately for the unemployed living in families with and without children (see Table 6 in Columns 2 and 3). The effect of social benefits (represented by the NRR) is negative and significant at the 5\% level for childless individuals, while it is not significant for those with children. This result points to the existence of a welfare trap within

\footnotetext{
${ }^{11}$ Low significance possibly arises because the presence of children delivers the reverse impact on labor supply behavior by gender. When the equation is estimated separately by gender, the presence of a threeto five-year-old child in the family translates to a lower probability of transitioning to work for women by 1.2 percentage points and the coefficient is significant at the $5 \%$ level. For men, the estimate implies a significant positive effect of 1.4 percentage points. The presence of older children in the family has no association with the dependent variable.

${ }^{12}$ I would like to thank Mikolaj Herbst, who suggested the robustness check. The results are available on request.
} 
the former group but not within the latter group. An alternative explanation consistent with the estimates is that social benefits attached to families with children are high (as shown in Table 5) though the variation in the NRR is insufficient to explain the outflow from unemployment. Accordingly, this means that the transition probability for this group is determined by factors other than the level of social benefits. Estimates suggest that it is rather the childless unemployed with low-earnings opportunities who are vulnerable to the welfare trap. To further support this argument, equation (5) is estimated separately for individuals with low (primary or lower secondary) and high (upper secondary or tertiary) educational attainment. Given that education is a strong predictor of labor income, the withdrawal of means-tested benefits associated with entering low-paid work can lead to no significant increase in total income in the case of low-educated individuals. The results in Columns 4 and 5 reveal that the effect appears to be concentrated in the groups with low education; indeed, for the group with high education, the effect is close to zero and statistically insignificant. Overall, the results reveal that relatively high social benefits constitute a welfare trap for potentially low-income workers and the existence of a welfare trap was not confirmed for those unemployed with children.

\subsection{Unemployment Duration Dependence}

The last three columns of Table 6 present the results from the specification containing individuals by the duration of unemployment. The negative duration dependence was confirmed by Sorm and Terrell (2000), implying that the longer an individual is unemployed, the less likely they are to leave that state. Negative dependency arises due to the unobserved heterogeneity that those who are unemployed for longer periods are less motivated or have other characteristics that render them less favorable to employers. According to that hypothesis, the welfare trap is more likely to be present among the long-term unemployed who have the lowest chances of improving their economic conditions in the labor market. The estimate on the NRR is negative and significant for the group of unemployed with a duration longer than two years, while coefficients are not significant for those unemployed with shorter durations. Estimates indicate that the long-term unemployment observed in the Czech labor market is accompanied by the existence of a welfare trap.

\subsection{Gender Differences}

As discussed above, women are disadvantaged in the transition from unemployment to employment. Relative to men, women face lower earnings possibilities and, consequently, the relative level of social benefits is higher for women. For this reason, the amount of social benefits can have a varying impact on the economic incentives of men and women to find a job. Equation (5) is estimated separately for men and women and for groups along different dimensions in Table 7 in order to examine whether there is a heterogeneous effect of social benefits on the labor supply behavior of men and women. The dimensions considered are the presence of children, education and unemployment duration. In general, the results reveal that women are more vulnerable to the welfare trap than men. The existence of a welfare trap is confirmed for women without children, the low-educated and the long-term unemployed, while the estimate on the NRR for women living in families with children is proven not to be significant. This also means that the transition probability for this 
group is determined by other factors (such as education, the economic status of the spouse, the age of the children, etc.) rather than the level of social benefits. For men, the average estimated coefficient on the NRR is negative and significant but is imprecisely estimated for the subgroups of the male sample. Finally, the estimates of models that include observations before and after 2000 are presented. ${ }^{13}$ These estimates are consistent with the findings of Sorm and Terrell (2000), who document that the labor market was characterized by high mobility of workers with short periods of unemployment prior to 2000. The existence of a welfare trap is confirmed in the period after 2000. The estimate on the NRR is significant for women at the $1 \%$ level, while it is not significant at the conventional level for men.

\subsection{Job-Search Intensity}

The theoretical framework derived in Section 4 demonstrates that higher jobsearch intensity increases transitions to employment. The relationship is tested empirically for the sub-sample in the period 2002-2005, given that the information on search channels is not provided for the whole period. Table 8 shows the estimates of the baseline model for the sub-sample together with the estimates separately by gender. Next to it, the equations are estimated with the additional control of jobsearch intensity. Estimates on search intensity provide evidence that those unemployed who use multiple job-search channels are more successful in finding a job and exiting unemployment. Importantly, the inclusion of the search intensity variable only slightly affects the estimates on the NRR. The existence of a welfare trap is documented for women; however, it is not significant for the total sub-sample $(t$ statistics are 1.54) and men ( $t$ statistics are 0.86).

\section{Conclusions}

The social security system in the Czech Republic has been assessed by several studies as generating potential disincentive effects (welfare trap) for some unemployed individuals. This paper combines the information from Czech Labor Force Surveys and the Czech Household Income Survey to demonstrate the effect of the tax and social security systems on individual flows from unemployment to employment. The analysis presents empirical evidence that relatively high social benefits reduce the incentives to exit unemployment for individuals with low-earnings opportunities in the labor market. The analysis documents the disadvantaged position of women in the Czech labor market. Due to lower earnings in employment, women face high replacement rates relative to men. The estimates imply that women's outflows to employment are particularly influenced by high social benefits and the existence of a welfare trap persists even when job-search intensity is controlled. This finding contributes to the discussion initiated by Lauerova and Terrell (2005) on the persistent and large unemployment gender gap in the Czech Republic.

In general, the findings agree with the previous research showing that labor market flows in the Czech Republic were efficient in the late 1990s and the existence of the welfare trap is confirmed in the period after 2000. The analysis uses data until 2005 and therefore further research is necessary to show whether the reform of the tax and social security systems introduced between 2007 and 2008 were effective

${ }^{13}$ The results are robust to the choice of split around 2000. 
to improve work incentives of the groups identified in this paper. Recent studies suggest that these reforms were not strong enough to significantly narrow the work incentives of low- and middle-income households (Pavel, 2009; Galuscak and Pavel, 2012). In another study, Dusek, Kaliskova and Munich (2013) calculate the effective participation tax rate (the proportion of gross earnings lost in tax and withdrawn benefits) using the Czech SILC 2011 household survey. The authors demonstrate high rates (when the rate approaches one, it means that there is no financial reward from work compared to non-work) among low income households and particularly for second earners (usually women).

The main findings from the analysis therefore remain relevant in the current situation and the policy reform will need to balance its redistributive aims with work incentives and particularly refocus incentives towards transition to work for lowskilled workers and women. This can be achieved with (i) an increase of the statutory minimum wage; (ii) a decrease of the marginal tax rate for low-income earners; and (iii) the phasing out of social benefits over a certain period instead of the sharp withdrawal of benefits. Ultimately, a better harmonization of the tax and social security systems in the direction of fewer social welfare programs and lower marginal tax rates will ensure that the incentives to leave unemployment are not hampered by high social benefits. Empirical findings also confirm that measures improving monitoring and the enforcement of job search are efficient in accelerating the transition to employment.

\section{APPENDIX 1}

\section{Figure 1 Unemployment Rate}

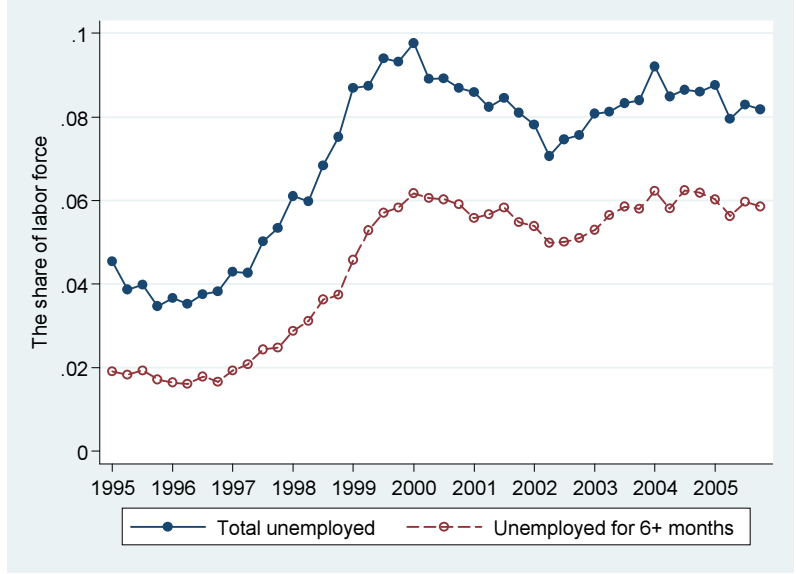

Source: Labor Force Survey 1995-2005, the Czech Republic 
Table 1 Minimum Subsistence Income

( $\%$ average of monthly net income)

\begin{tabular}{lllll|lclll}
\hline Year & \multicolumn{3}{c}{ Personal benefit depends on age } & \multicolumn{5}{c}{$\begin{array}{c}\text { Household supplement } \\
\text { depends on household size }\end{array}$} \\
\hline & $0-5$ & $6-9$ & $10-15$ & above 16 & 1 & 2 & 3 & 4 & 5 \\
\hline 1995 & 27 & 20 & 22 & 26 & 12 & 16 & 20 & 20 & 22 \\
1996 & 24 & 18 & 20 & 23 & 13 & 17 & 21 & 21 & 24 \\
1997 & 24 & 18 & 20 & 23 & 12 & 16 & 20 & 20 & 22 \\
1998 & 23 & 17 & 19 & 22 & 14 & 19 & 23 & 23 & 26 \\
1999 & 22 & 16 & 18 & 21 & 16 & 21 & 26 & 26 & 29 \\
2000 & 21 & 15 & 17 & 20 & 15 & 20 & 25 & 25 & 28 \\
2001 & 20 & 15 & 17 & 20 & 16 & 20 & 25 & 25 & 28 \\
2002 & 19 & 14 & 15 & 19 & 15 & 19 & 24 & 24 & 26 \\
2003 & 18 & 13 & 15 & 18 & 14 & 18 & 22 & 22 & 25 \\
2004 & 17 & 12 & 14 & 17 & 13 & 17 & 21 & 21 & 24 \\
2005 & 16 & 12 & 13 & 16 & 13 & 18 & 22 & 22 & 24 \\
\hline
\end{tabular}

Note: Amounts are computed relative to the nominal monthly net income of an average production worker living in a single household (see Column 2 in Table 4)

Source: Author's computations based on information from the Ministry of Labor and Social Affairs.

Table 2 Minimum Subsistence Income by Household Type ( $\%$ average of monthly net income)

\begin{tabular}{lcccc}
\hline Year & Single & $\begin{array}{c}\text { Single+ } \\
\text { +children }\end{array}$ & Couple & $\begin{array}{c}\text { Couple+ } \\
\text { +children }\end{array}$ \\
\hline 1995 & 38 & 92 & 67 & 117 \\
1996 & 36 & 86 & 63 & 109 \\
1997 & 35 & 85 & 62 & 108 \\
1998 & 37 & 86 & 64 & 108 \\
1999 & 37 & 86 & 64 & 107 \\
2000 & 36 & 81 & 60 & 102 \\
2001 & 36 & 81 & 61 & 101 \\
2002 & 33 & 75 & 57 & 94 \\
2003 & 32 & 71 & 54 & 89 \\
2004 & 30 & 67 & 50 & 84 \\
2005 & 29 & 66 & 49 & 82 \\
\hline
\end{tabular}

Notes: Subsistence is computed from Table 1 as the sum of personal benefits for all family members and the household supplement. A family with two children aged 3 and 8 is assumed.

Source: Author's computations based on information from the Ministry of Labor and Social Affairs. 
Table 3 Summary Statistics-Individual Characteristics

\begin{tabular}{|c|c|c|c|c|c|c|}
\hline & $\begin{array}{l}\text { Total } \\
\text { mean }\end{array}$ & s.dev & $\begin{array}{c}\text { Men } \\
\text { mean }\end{array}$ & s.dev & $\begin{array}{c}\text { Women } \\
\text { mean }\end{array}$ & s.dev \\
\hline $\mathrm{N}$ & 28338 & & 9384 & & 18954 & \\
\hline Transition to employment & 0.09 & 0.29 & 0.09 & 0.29 & 0.09 & 0.29 \\
\hline Female & 0.67 & 0.47 & & & & \\
\hline Married & 0.61 & 0.49 & 0.56 & 0.50 & 0.63 & 0.48 \\
\hline Spouse is employed & 0.48 & 0.50 & 0.31 & 0.46 & 0.57 & 0.50 \\
\hline No children & 0.38 & 0.49 & 0.48 & 0.50 & 0.33 & 0.47 \\
\hline Child 0-2y & 0.04 & 0.20 & 0.11 & 0.32 & 0.01 & 0.08 \\
\hline Child 3-5y & 0.15 & 0.36 & 0.13 & 0.33 & 0.17 & 0.37 \\
\hline Child 6-9y & 0.25 & 0.43 & 0.18 & 0.38 & 0.28 & 0.45 \\
\hline Child 10-15y & 0.30 & 0.46 & 0.23 & 0.42 & 0.33 & 0.47 \\
\hline Edu: primary & 0.33 & 0.47 & 0.35 & 0.48 & 0.32 & 0.47 \\
\hline Edu: lower sec & 0.45 & 0.50 & 0.50 & 0.50 & 0.42 & 0.49 \\
\hline Edu: upper sec & 0.20 & 0.40 & 0.12 & 0.33 & 0.24 & 0.43 \\
\hline Edu: tertiary & 0.03 & 0.16 & 0.03 & 0.18 & 0.02 & 0.14 \\
\hline Age & 39.81 & 9.10 & 40.91 & 9.25 & 39.26 & 8.98 \\
\hline Spell $0.5-1$ years & 0.32 & 0.47 & 0.31 & 0.46 & 0.32 & 0.47 \\
\hline Spell 1-2 years & 0.28 & 0.45 & 0.27 & 0.44 & 0.28 & 0.45 \\
\hline Spell >2 years & 0.41 & 0.49 & 0.42 & 0.49 & 0.40 & 0.49 \\
\hline Before un.: employment & 0.76 & 0.43 & 0.88 & 0.33 & 0.70 & 0.46 \\
\hline Before un.: household & 0.08 & 0.27 & 0.01 & 0.08 & 0.11 & 0.32 \\
\hline Before un.: childcare & 0.09 & 0.28 & 0.00 & 0.04 & 0.13 & 0.33 \\
\hline Before un.: other & 0.08 & 0.27 & 0.12 & 0.32 & 0.06 & 0.24 \\
\hline Partial disability & 0.13 & 0.34 & 0.15 & 0.36 & 0.12 & 0.33 \\
\hline Search intensity & 3.74 & 1.24 & 3.71 & 1.24 & 3.75 & 1.23 \\
\hline
\end{tabular}

Note: Information on search intensity is only available for the 2002-2005 period.

Source: Labor Force Survey 1995-2005, the Czech Republic. 
Table 4 Wage Level and Unemployment Rate Statistics at National and District Level

\begin{tabular}{|c|c|c|c|c|c|c|}
\hline \multirow{3}{*}{ Year } & \multicolumn{2}{|c|}{ National avg } & \multicolumn{2}{|c|}{$\begin{array}{c}\text { Avg wage in districts } \\
\text { as } \% \text { of (1) }\end{array}$} & \multicolumn{2}{|c|}{$\begin{array}{l}\text { Unemployment rate } \\
\text { in districts }\end{array}$} \\
\hline & $\begin{array}{c}\text { gross wage } \\
\text { (CZK) }\end{array}$ & $\begin{array}{l}\text { net wage } \\
\text { (CZK) }\end{array}$ & $\begin{array}{l}\text { lower } \\
\text { quintile }\end{array}$ & $\begin{array}{c}\text { upper } \\
\text { quintile }\end{array}$ & $\begin{array}{c}\text { lower } \\
\text { quintile }\end{array}$ & $\begin{array}{c}\text { upper } \\
\text { quintile }\end{array}$ \\
\hline & (1) & (2) & (3) & (4) & (5) & (6) \\
\hline 1995 & 8170 & 6291 & 86 & 107 & 1.15 & 5.83 \\
\hline 1996 & 9684 & 7457 & 86 & 106 & 1.47 & 6.73 \\
\hline 1997 & 10698 & 8344 & 85 & 106 & 2.53 & 9.50 \\
\hline 1998 & 11709 & 9133 & 84 & 107 & 4.06 & 12.53 \\
\hline 1999 & 12651 & 9868 & 84 & 107 & 5.20 & 15.48 \\
\hline 2000 & 13484 & 10383 & 83 & 106 & 4.35 & 15.60 \\
\hline 2001 & 14793 & 11391 & 80 & 103 & 4.49 & 15.42 \\
\hline 2002 & 15857 & 12210 & 79 & 102 & 5.14 & 16.62 \\
\hline 2003 & 16917 & 12857 & 80 & 102 & 5.61 & 17.38 \\
\hline 2004 & 18035 & 13707 & 80 & 102 & 5.83 & 17.08 \\
\hline 2005 & 18937 & 14392 & 80 & 102 & 4.88 & 15.24 \\
\hline
\end{tabular}

Notes: The average nominal gross monthly wage (in CZK) and registered unemployment rate were collected in 77 districts. The average nominal net wage (in CZK) assumes the effective tax rate of a single person without children. In every year, districts are divided into quintiles by the level of the average gross wage and unemployment rate. Average values for districts in lower and upper quintiles are reported.

Source: Czech Statistical Office.

Table 5 Net Replacement Rate of Different Groups in the Sample

\begin{tabular}{|c|c|c|c|c|c|c|c|c|c|c|}
\hline Year & Total & Men & Women & $\begin{array}{l}\text { Child- } \\
\text { less }\end{array}$ & $\begin{array}{c}\text { Has } \\
\text { children }\end{array}$ & $\begin{array}{l}\text { Low } \\
\text { edu }\end{array}$ & $\begin{array}{l}\text { High } \\
\text { edu }\end{array}$ & $\begin{array}{c}\text { Spell } \\
0.5-1 y\end{array}$ & $\begin{array}{l}\text { Spell } \\
1-2 y\end{array}$ & $\begin{array}{c}\text { Spel } \\
>2 y\end{array}$ \\
\hline 1995 & 0.74 & 0.67 & 0.77 & 0.61 & 0.79 & 0.76 & 0.63 & 0.72 & 0.73 & 0.80 \\
\hline 1996 & 0.72 & 0.63 & 0.76 & 0.59 & 0.78 & 0.74 & 0.62 & 0.71 & 0.72 & 0.77 \\
\hline 1997 & 0.70 & 0.63 & 0.74 & 0.59 & 0.77 & 0.73 & 0.62 & 0.70 & 0.68 & 0.76 \\
\hline 1998 & 0.71 & 0.64 & 0.74 & 0.60 & 0.77 & 0.74 & 0.62 & 0.68 & 0.71 & 0.76 \\
\hline 1999 & 0.71 & 0.65 & 0.75 & 0.61 & 0.77 & 0.75 & 0.61 & 0.68 & 0.71 & 0.76 \\
\hline 2000 & 0.70 & 0.62 & 0.73 & 0.58 & 0.76 & 0.73 & 0.59 & 0.68 & 0.69 & 0.73 \\
\hline 2001 & 0.69 & 0.61 & 0.73 & 0.59 & 0.75 & 0.71 & 0.61 & 0.66 & 0.69 & 0.71 \\
\hline 2002 & 0.68 & 0.60 & 0.73 & 0.57 & 0.76 & 0.71 & 0.59 & 0.66 & 0.67 & 0.70 \\
\hline 2003 & 0.67 & 0.58 & 0.71 & 0.55 & 0.74 & 0.69 & 0.57 & 0.64 & 0.66 & 0.69 \\
\hline 2004 & 0.65 & 0.56 & 0.70 & 0.55 & 0.73 & 0.68 & 0.54 & 0.61 & 0.64 & 0.68 \\
\hline 2005 & 0.64 & 0.54 & 0.69 & 0.54 & 0.71 & 0.67 & 0.54 & 0.63 & 0.62 & 0.66 \\
\hline $\begin{array}{l}\text { average } \\
\text { NRR }\end{array}$ & 0.69 & 0.60 & 0.73 & 0.57 & 0.75 & 0.71 & 0.59 & 0.67 & 0.68 & 0.71 \\
\hline $\begin{array}{l}\% \text { NNR> } \\
>0.8\end{array}$ & 0.21 & 0.17 & 0.23 & 0.10 & 0.28 & 0.26 & 0.03 & 0.15 & 0.19 & 0.28 \\
\hline
\end{tabular}

Note: Individuals with a low level of education are defined as those who have primary and lower secondary education. Individuals with upper secondary and tertiary education are defined as having a high level of education.

Source: Author's computations based on the Labor Force Survey and Czech Household Income Survey. 


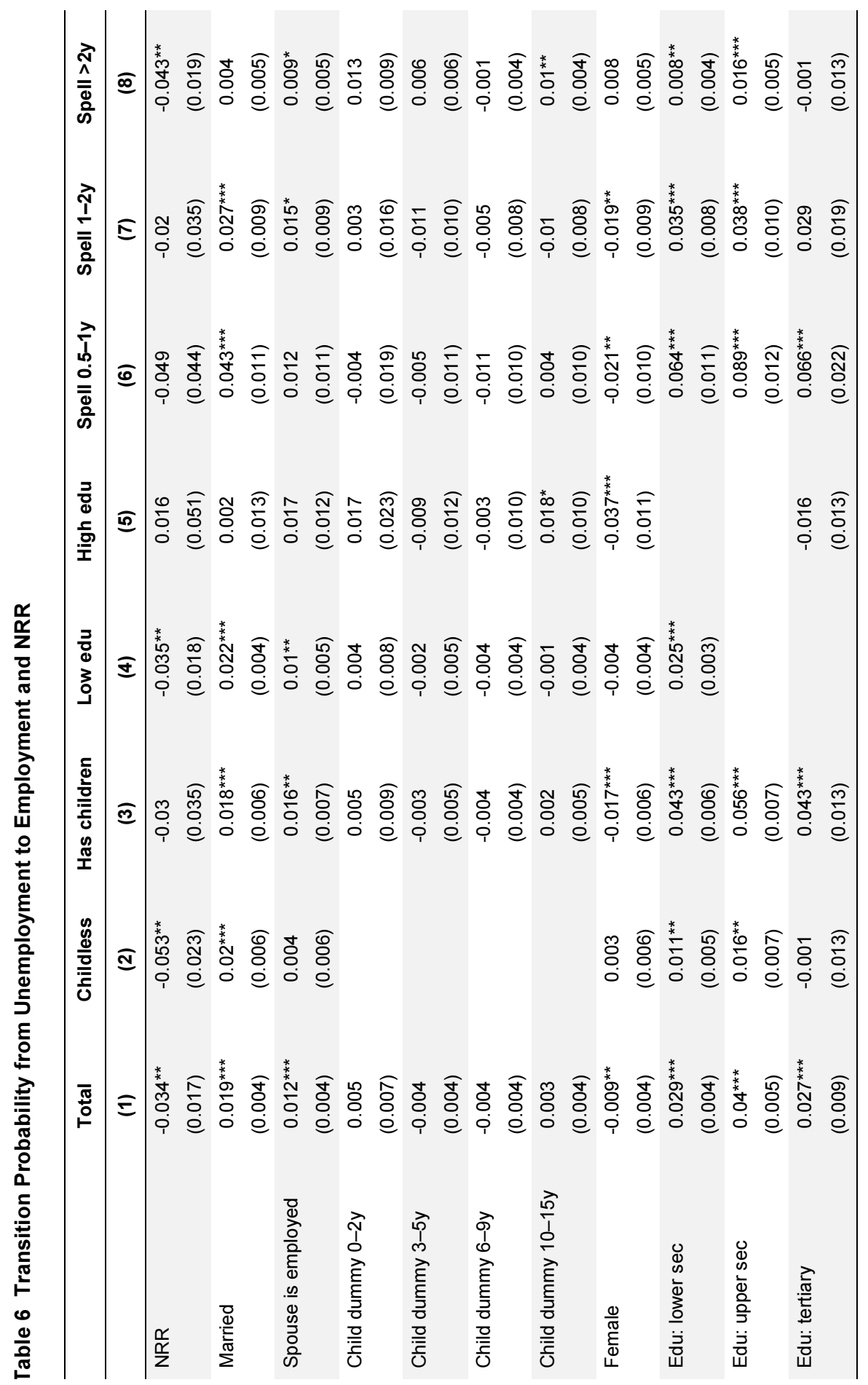




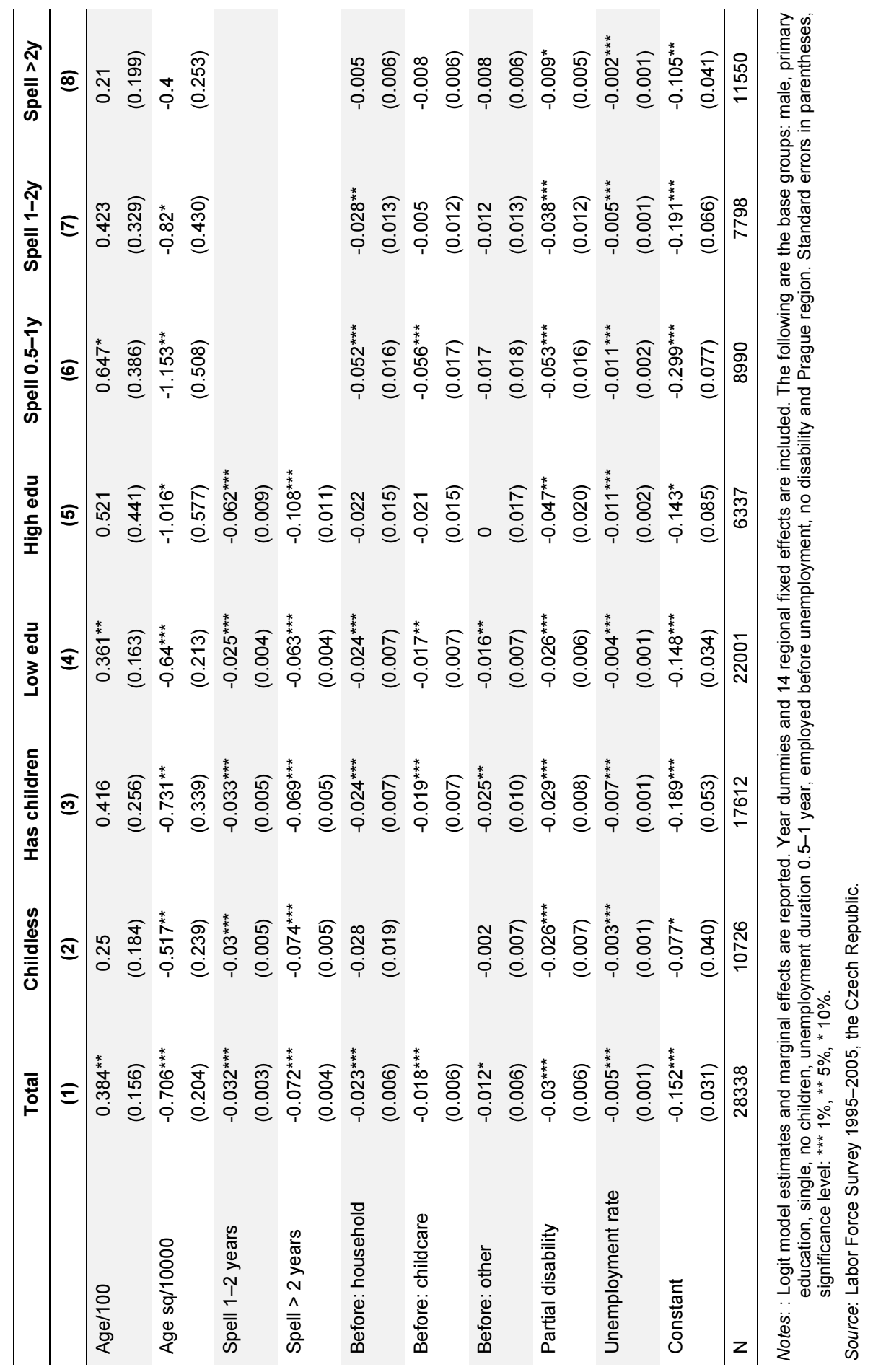


Table 7 Estimates of NRR for Different Groups by Gender

\begin{tabular}{|c|c|c|c|}
\hline & Total & Men & Women \\
\hline \multirow[t]{2}{*}{ All } & $-0.034^{\star \star}$ & $-0.043^{*}$ & $-0.059^{* *}$ \\
\hline & $(0.017)$ & $(0.026)$ & $(0.023)$ \\
\hline \multirow[t]{2}{*}{ Childless } & $-0.053^{\star *}$ & -0.040 & $-0.077^{\star \star}$ \\
\hline & $(0.023)$ & $(0.036)$ & $(0.030)$ \\
\hline \multirow[t]{2}{*}{ Has children } & -0.030 & -0.073 & -0.015 \\
\hline & $(0.035)$ & $(0.070)$ & $(0.043)$ \\
\hline \multirow[t]{2}{*}{ Low edu } & $-0.035^{\star \star}$ & -0.028 & $-0.078^{\star \star \star}$ \\
\hline & $(0.018)$ & $(0.026)$ & $(0.027)$ \\
\hline \multirow[t]{2}{*}{ High edu } & 0.016 & -0.174 & 0.039 \\
\hline & $(0.051)$ & $(0.112)$ & $(0.062)$ \\
\hline \multirow[t]{2}{*}{ Spell $0.5-1$ years } & -0.049 & -0.116 & -0.047 \\
\hline & $(0.044)$ & $(0.074)$ & $(0.062)$ \\
\hline \multirow[t]{2}{*}{ Spell 1-2 years } & -0.020 & 0.032 & $-0.106^{\star \star}$ \\
\hline & $(0.035)$ & $(0.057)$ & $(0.049)$ \\
\hline \multirow[t]{2}{*}{ Spell >2 years } & $-0.043^{\star *}$ & -0.040 & $-0.057^{\star *}$ \\
\hline & $(0.019)$ & $(0.025)$ & $(0.027)$ \\
\hline \multirow[t]{2}{*}{ Year 1995-2000 } & -0.018 & -0.031 & -0.023 \\
\hline & $(0.027)$ & $(0.041)$ & $(0.039)$ \\
\hline \multirow[t]{2}{*}{ Year 2001-2005 } & $-0.044^{\star *}$ & -0.043 & $-0.088^{* * *}$ \\
\hline & $(0.022)$ & $(0.034)$ & $(0.031)$ \\
\hline
\end{tabular}

Notes: Figures in the table are the estimates of NRR from separate regressions. All models have the same specification as in Table 6. Standard errors in parenthesis, significance level: ${ }^{\star \star *} 1 \%,{ }^{\star *} 5 \%,{ }^{*} 10 \%$.

Source: Labor Force Survey 1995-2005, the Czech Republic

Table 8 Estimates of NRR and Search Intensity

\begin{tabular}{lcccccc}
\hline & Total & Men & Women & Total & Men & Women \\
& $\mathbf{( 1 )}$ & $\mathbf{( 2 )}$ & $\mathbf{( 3 )}$ & $\mathbf{( 4 )}$ & $\mathbf{( 5 )}$ & $\mathbf{( 6 )}$ \\
\hline NRR & $-0,038$ & $-0,033$ & $-0,067^{* *}$ & $-0,037$ & $-0,033$ & $-0,064$ \\
& $(0.024)$ & $(0.039)$ & $(0.034)$ & $(0.024)$ & $(0.039)$ & $(0.034)$ \\
Search intensity & & & & $0,005^{\star * *}$ & $0,006^{* *}$ & $0,004^{* *}$ \\
& & & & $(0.002)$ & $(0.003)$ & $(0.002)$ \\
\hline N & 12699 & 4242 & 8457 & 12699 & 4242 & 8457 \\
\hline
\end{tabular}

Notes: The sample is limited to the period 2002-2005. All models have the same specification as in Table 6 . Standard errors in parenthesis, significance level: ${ }^{* *} 1 \%,{ }^{* *} 5 \%,{ }^{*} 10 \%$.

Source: Labor Force Survey 1995-2005, the Czech Republic 


\section{APPENDIX 2}

Heckman's sample selection model is applied to estimate a wage equation controlling for the selection into employment. In the first step, the probit selection equation is formulated:

$$
P\left(E_{i}=1 \mid Z_{i}\right)=\Phi\left(Z_{i} \gamma\right)
$$

where $Z$ includes different explanatory variables that affect the likelihood of participation of individuals in waged work $\left(E_{i}=1\right)$. The predicted values from the probit regression are used to calculate the Inverse Mills Ratio (IMR) for each observation in the sample:

$$
I M R_{i}=\frac{\phi\left(Z_{i} \gamma\right)}{1-\Phi\left(Z_{i} \gamma\right)}
$$

where $\phi($.$) and \Phi($.$) are the density function and distribution function of the stand-$ ard normal distribution, respectively. In the second step, IMR is added as an additional explanatory variable in the Mincerian wage model:

$$
W_{i}^{*}=\mathbf{X}_{\mathrm{i}} \beta+\beta_{I M R} I M R_{i}+\varepsilon_{i}
$$

where $W_{i}^{*}$ is the wage, and vector $\mathbf{X}_{\mathrm{i}}$ includes observed variables relating to the worker's productivity, and $\varepsilon_{i}$ is an error term. $\beta_{I M R}$ is the covariance between the error terms from the wage and selection equations. Error terms in both equations are assumed to be jointly normally distributed. The IMR as an additional regressor accounts for the bias due to the non-random nature of the sample of wage earners. The system is estimated separately for men and women. The results presented in Table 10 imply that the presence of young children in the household is associated with the lower participation rate of women and less so in the case of men. The availability of other household income has negative associations with participation while the presence of another employed person in the household implies the lower participation of women. The significant estimate on IMR in the wage regression points to the negative selection into employment. Estimating the potential entry-level income of unemployed workers in the local labor market, the choice of variables in the wage regression is limited due to the fact that the prediction of income for the sample of unemployed workers does not allow us to consider work characteristics (the same approach is used in Schneider and Uhlendorff, 2006). The estimated parameters $P\left(E_{i}=1 \mid Z_{i}\right)=\Phi\left(Z_{i} \gamma\right)$ of the log-wage equation are used to calculate a potential monthly full-time gross wage of every individual in the LFS. The wages for years other than 2002 are subsequently adjusted for the regional wage growth. Predicted gross monthly earnings that fell below the Czech statutory gross minimum wage (180 cases) were set to the respective level of the minimum wage. 
Table 9 Wage Estimation (Heckman's Sample Selection Model)

\begin{tabular}{|c|c|c|c|c|c|}
\hline \multicolumn{3}{|c|}{ Eq. 1: selection to employment } & \multicolumn{3}{|c|}{ Eq. 2: logarithm of gross monthly wage } \\
\hline & Women & Men & & Women & Men \\
\hline Work experience & $\begin{array}{l}-0.001 \\
(0.013)\end{array}$ & $\begin{array}{c}0.057^{\star \star \star} \\
(0.016)\end{array}$ & Work experience & $\begin{array}{l}0.008^{\star \star \star} \\
(0.003)\end{array}$ & $\begin{array}{l}0.02^{\star \star \star} \\
(0.003)\end{array}$ \\
\hline Work experience sq. /100 & $\begin{array}{c}0.018 \\
(0.032)\end{array}$ & $\begin{array}{l}-0.132^{\star \star \star} \\
(0.039)\end{array}$ & Work experience sq. $/ 100$ & $\begin{array}{l}-0.011^{*} \\
(0.006)\end{array}$ & $\begin{array}{c}-0.043^{\star \star \star} \\
(0.007)\end{array}$ \\
\hline Edu: lower sec & $\begin{array}{l}0.606^{\star * *} \\
(0.092)\end{array}$ & $\begin{array}{c}0.95^{\star * \star} \\
(0.110)\end{array}$ & Edu: lower sec & $\begin{array}{l}0.109^{\star * *} \\
(0.026)\end{array}$ & $\begin{array}{c}0.064^{*} \\
(0.038)\end{array}$ \\
\hline Edu: upper sec & $\begin{array}{l}0.789^{\star \star \star *} \\
(0.095)\end{array}$ & $\begin{array}{c}1.264^{\star \star \star} \\
(0.127)\end{array}$ & Edu: upper sec & $\begin{array}{l}0.424^{\star \star *} \\
(0.027)\end{array}$ & $\begin{array}{l}0.293^{\star \star \star} \\
(0.042)\end{array}$ \\
\hline Edu: tertiary & $\begin{array}{l}1.000^{\star \star \star} \\
(0.132)\end{array}$ & $\begin{array}{c}1.405^{\star \star \star} \\
(0.181)\end{array}$ & Edu: tertiary & $\begin{array}{l}0.714^{\star \star \star} \\
(0.032)\end{array}$ & $\begin{array}{c}0.6^{\star \star \star} \\
(0.045)\end{array}$ \\
\hline Partial disability & $\begin{array}{l}-1.730^{\star \star \star} \\
(0.167)\end{array}$ & $\begin{array}{l}-1.417^{\star \star \star} \\
(0.171)\end{array}$ & Partial disability & $\begin{array}{c}-0.363^{\star \star \star} \\
(0.078)\end{array}$ & $\begin{array}{c}-0.389^{\star \star \star} \\
(0.072)\end{array}$ \\
\hline Married & $\begin{array}{c}0.043 \\
(0.065)\end{array}$ & $\begin{array}{c}0.683^{\star * \star} \\
(0.094)\end{array}$ & The inverse Mills ratio & $\begin{array}{c}-0.076^{\star * *} \\
(0.026)\end{array}$ & $\begin{array}{c}-0.265^{\star \star *} \\
(0.074)\end{array}$ \\
\hline Child dummy $0-2 y$ & $\begin{array}{l}-1.984^{\star \star \star} \\
(0.086)\end{array}$ & $\begin{array}{l}-0.077 \\
(0.133)\end{array}$ & Constant & $\begin{array}{l}9.163^{\star \star \star} \\
(0.038)\end{array}$ & $\begin{array}{l}9.446^{\star \star \star} \\
(0.058)\end{array}$ \\
\hline Child dummy $3-5 y$ & $\begin{array}{l}-1.347^{\star \star \star} \\
(0.082)\end{array}$ & $\begin{array}{l}-0.271^{\star *} \\
(0.137)\end{array}$ & $\begin{array}{l}\mathrm{N} \\
\mathrm{R} 2 \\
\end{array}$ & $\begin{array}{l}3121 \\
0.354 \\
\end{array}$ & $\begin{array}{l}3202 \\
0.328 \\
\end{array}$ \\
\hline Child dummy 6-9y & $\begin{array}{l}-0.391^{\star \star \star} \\
(0.075)\end{array}$ & $\begin{array}{l}-0.05 \\
(0.124)\end{array}$ & & & \\
\hline Child dummy $10-15 y$ & $\begin{array}{l}-0.083 \\
(0.070)\end{array}$ & $\begin{array}{l}-0.11 \\
(0.098)\end{array}$ & & & \\
\hline Other household income & $\begin{array}{l}-0.040^{*} \\
(0.024)\end{array}$ & $\begin{array}{l}-0.156^{\star \star \star} \\
(0.030)\end{array}$ & & & \\
\hline Other econ. active person & $\begin{array}{l}-0.410^{* \star *} \\
(0.038)\end{array}$ & $\begin{array}{l}-0.045 \\
(0.050)\end{array}$ & & & \\
\hline City size $5,000-50,000$ & $\begin{array}{r}0.132^{*} \\
(0.069)\end{array}$ & $\begin{array}{c}0.156^{*} \\
(0.090)\end{array}$ & & & \\
\hline City size $50,000-100,000$ & $\begin{array}{c}0.188^{*} \\
(0.109)\end{array}$ & $\begin{array}{l}0.309^{* *} \\
(0.144)\end{array}$ & & & \\
\hline City size above 100,000 & $\begin{array}{l}-0.124 \\
(0.113)\end{array}$ & $\begin{array}{l}-0.15 \\
(0.141)\end{array}$ & & & \\
\hline Unemployment rate & $\begin{array}{l}-0.036^{\star \star \star} \\
(0.012)\end{array}$ & $\begin{array}{l}-0.041^{* *} \\
(0.016)\end{array}$ & & & \\
\hline Constant & $\begin{array}{l}1.495^{\star \star \star} \\
(0.204)\end{array}$ & $\begin{array}{c}0.779^{\star \star \star} \\
(0.266)\end{array}$ & & & \\
\hline $\mathrm{N}$ & 4019 & 3473 & & & \\
\hline Pseudo $R^{2}$ & 0.378 & 0.2448 & & & \\
\hline
\end{tabular}

Notes: Estimation method: probit model for the selection equation and OLS regression for the wage equation. The sample includes individuals aged 18-54 years old who are unemployed or full-time employees (excluding self-employed, students and persons working less than 30 hours per week). Work experience equals age minus 6 minus imputed years of schooling. Fourteen regional fixed effects are included in both equations. Standard errors in parentheses, significance level: ${ }^{\star \star *} 1 \%,{ }^{\star *} 5 \%,{ }^{\star} 10 \%$.

Source: Czech Household Income Survey, 2002. 


\section{REFERENCES}

Bicakova A (2010): Gender Unemployment Gaps: Evidence from the New EU Member States. CERGE-EI Working Paper Series, no. 410.

Boeri T (2000): Structural change, welfare systems, and labour reallocation: Lessons from the transition of formerly planned economies. New York, Oxford University Press.

Commander S, Heitmueller A (2007): Does unemployment insurance help explain unemployment in transition countries? Available at: http://www.iza.org/conference_files/worldb2007/program.

Dusek L, Kaliskova K, Munich D (2013): Distribution of Average, Marginal and Participation Tax Rates among Czech Taxpayers: Results from a TAXBEN Model. Finance a úvěr-Czech Journal of Economics and Finance, 63(6):474-504.

European Commission (2004): Employment in Europe 2004: recent trends and prospects. http://europa.eu/legislation_summaries/employment_and_social_policy/situation_in_europe/c10137 en.htm

Filer RK, Jurajda S, Planovsky J (1999): Education and wages in the Czech and Slovak Republics during transition. Labour Economics, 6(4):581-593.

Flek V, Vecernik J (2005): The labor market in the Czech Republic: trends, policies and attitudes. Finance a úvěr-Czech Journal of Economics and Finance, 55(1-2):5-24.

Galuscak K, Munich D (2007): Structural and Cyclical Unemployment: What Can We Derive from the Matching Function? Finance a úvěr-Czech Journal of Economics and Finance, 57(3-4):102-125.

Galuscak K, Pavel J (2007): Unemployment and Inactivity Traps in the Czech Republic: Incentive Effects of Policies. Czech National Bank Working Paper, no. 2007/9.

Ham JC, Svejnar J, Terrell K (1998): Unemployment and the social safety net during transitions to a market economy: evidence from the Czech and Slovak Republics. American Economic Review, 88(5):1117-1142.

Heckman JJ (1979): Sample selection bias as a specification error. Econometrica, 47(1):153-161.

Jahoda R (2004): Interakce sociálního a daňového systému a pracovní pobídky [Work incentives and interaction between tax and social systems], Prague, VUPSV (Research Institute for Labour and Social Affairs - RILSA).

Jurajda S (2003): Gender wage gap and segregation in enterprises and the public sector in late transition countries. Journal of Comparative Economics, 31(2):199-222.

Jurajda S, Munich D (2003): Understanding long-term unemployment in the Czech Republic. Finance a úvěr-Czech Journal of Economics and Finance, 53(1-2):11-30.

Jurajda S, Zubricky J (2005): Employment Incentives in the Czech Republic: Comparing Current and Proposed Social Support Systems. CERGE-EI Working Paper Series, no. 147.

Lauerova JS, Terrell K (2005): Explaining Gender Differences in Unemployment with Micro Data on Flows in Post-Communist Economies. Comparative Economic Studies, 49(1):128-155.

Lehmann H, Muravyev A (2009): How Important Are Labor Market Institutions for Labor Market Performance in Transition Countries? IZA Discussion Paper, no. 5905.

Mareš P (2001): Problém nečerpání sociálních dávek [Non-take up of social benefits problem]. Prague, VUPSV (Research Institute for Labour and Social Affairs - RILSA).

Mares P, Sirovatka T (2005): Unemployment, Labour Marginalisation, and Deprivation. Finance a úvěr-Czech Journal of Economics and Finance, 55(1-2):54-67.

Mortensen DT (1986): Job search and labor market analysis. In: Ashenfelter O, Layard R (Eds.): Handbook of Labor Economics. Edition 1, Volume 2, Chapter 15, pp. 849-919. Elsevier.

Munich D, Svejnar J, Terrell K (2005): Do Markets Favor Women's Human Capital More than Planners? Journal of Comparative Economics, 33(2):278-298.

OECD (1998): OECD Economic Surveys: Czech Republic.

OECD (2004): OECD Economic Surveys: Czech Republic. 
Ours JC van, Vodopivec M (2006): How shortening the potential duration of unemployment benefits affects the duration of unemployment: Evidence from a natural experiment. Journal of Labor Economics, 24(2):351-378.

Pavel J (2009): Dopady změn v daňovém a dávkovém systému v letech 2004-2008 na hodnoty ukazatelů motivace $\mathrm{k}$ práci $\mathrm{v} \breve{C} \mathrm{R}$. [Impact of changes in taxation and benefit systems from 2004 to 2008 on values of motivation-to-work indicators in the Czech Republic]. Ministry of Finance of the Czech Republic Research Study.

Petrongolo B (2009): The long-term effects of job search requirements: Evidence from the UK JSA reform. Journal of Public Economics, 93(11):1234-1253.

Portugal P, Addison JT (2008): Six Ways to Leave Unemployment. Scottish Journal of Political Economy, 55(4):393-419.

Prusa L (2001): Social Security and Tax System in the Czech Republic: Recent History and Outlook. Finance a úvěr-Czech Journal of Economics and Finance, 51(12):658-675.

Schneider H, Uhlendorff A (2005): Transitions from Welfare to Employment: Does the Ratio between Labor Income and Social Assistance Matter? Journal of Applied Social Science Studies, 125(1):51-61.

Schneider O (2004): Who Pays Taxes and Who Gets Benefits in the Czech Republic. (Charles University Prague, Faculty of Social Sciences, Institute of Economic Studies), Working Papers IES, no. 68.

Sorm V, Terrell K (2000): Sectoral restructuring and labor mobility: A comparative look at the Czech Republic. Journal of Comparative Economics, 28(3):431-455.

Wulfgramm M, Fervers L (2013): Unemployment and subsequent employment stability: Does labour market policy matter? IZA Discussion Paper, no. 7193. 